Are supernormal powers and conditions necessary to explain the immunity of Kuda Bux? Mr. Harry Price regards it as definitely proved that the ash plays no part as a protection. But ash forms very quickly as the surface-carbon oxidises away (especially under fanning ?), and a very thin layer is a protection, as anyone can testify by experiment with a finger and a red-hot stick. The photographs $^{6}$ seem to show a plentiful supply of ash in his path unless the red glow has photographed white. Mr. C. R. Darling ${ }^{7}$, on the other hand, says the surface walked was not visibly red-hot. Regarding his foot-soles, to the medical man who examined them before the first experiment, the epidermis seemed rather thick (although Mr. Price considered it was thin and tender).

On the second occasion, Prof. Pannett found "the skin was not callous but soft as the skin of so many individuals who walk barefoot [sic]". The feet were also noted as cold and dry. But callus is thickened-not necessarily hard-skin. The softness therefore need not exclude thickness. The thickness was not tested. The coldness and softness may have been caused by water (cf. Dr. Fulton above), the coldness enhanced by 'selfsuggestion's.
Regarding Mr. Price's test with the calicowrapped boot-last, it is not evident from the account that he raised and lowered it synchronously with one foot of Kuda Bux, that is, twice for half a second's contact. As the calico was scorched (he says) in one second and burned in two seconds, it seems indeed that the test was not properly applied. This lends force to Mr. Darling's findings as to the heat of the surface trodden.

Mr. Darling's positive evidence, then, regarding the heat of the trodden surface, and the uncertainty (pace Mr. Price) regarding the ash and the 'callosity' of the foot-soles of Kuda Bux, leaves the question of supernormality in the firewalk very much where it was.

\footnotetext{
1 "Indian Fakirs", St. Bartholomew's Hospital Journal, Oct.-Dec. 1934

" "Psychology and Psychotherapy", p. 108 et seq.

${ }^{3}$ Cf. Dr. Hadfleld's experiments (Lancet, Nov. 3, 1917) with a hypnotised patient, whose arm was only lightly blistered without hyperæmia when touched with a red-hot pencil-case.

- NATURE, 64, 397 (1901).

${ }^{3}$ NATURE, 67, 130 (1902).

- Listener, September 18, 1935.

7 Listener, November 6, 1935.

8 Dr. William Brown (loc. cit.) "Under autohypnosis the respiration can be slowed, the pulse-rate altered, the tendency to bleed diminished". Kuda Bux pulse rates and breathing rates have not been published, if they were taken.
}

\title{
Obituary
}

Captain S. R. Douglas, F.R.S.

$\mathrm{T}$ HE death of Captain S. R. Douglas, on January 20, after a short illness, will be deoply regretted by all who are interested in medical research. He was born in 1871 and educated at Haileybury College and St. Bartholomew's Hospital. After taking the double diploma M.R.C.S., L.R.C.P. in 1896, he joined the Indian Medical Service in 1898 as surgeon lieutenant. $\mathrm{He}$ served with the Plague Commission in 1899, and with the China Expedition in 1900-1, being promoted captain. He was invalided home at the end of 1901, but in spite of poor health, he soon took up work at St. Mary's Hospital with Sir Almroth Wright. In 1903, Wright and Douglas communicated to the Royal Society an important paper on the role of the body fluids in phagocytosis, a paper which did much to stimulate new work on vaceines and vaccine therapy. In both these lines of study Douglas played his part.

On August 1, 1914, Douglas joined the pathological staff of the Medical Research Committee, but the War interfered with projected research schemes, and he joined the R.A.M.C. After a short period of research work in France, he was invalided home, and in spite of continued ill-health, he was busily engaged in the production of vaccines on a large scale, the study of war wound infections and bacillary dysentery. In 1914, he described the method of preparation of a tryptic digest medium for cultivation of bacteria. This was of great immediate value for vaccine production, and has since proved to be of great value for general purposes.

From 1920 onwards to the close, Douglas was engaged in building up the Department of Experimental Pathology at the National Institute for Medical Research at Hampstead, and in pressing forward the work of others. In 1921, he was director of the Depart. ment, and in 1930 deputy director of the Institute. $\mathrm{He}$ was greatly interested in, and had an extensive knowledge of, virus diseases, and though he did not publish much on this subject, he did much to initiate new lines of work and assist his juniors. On occasion he started and guided an entire research, though his name did not appear on the final publication. $\mathrm{He}$ also did much during the period to assist in work with visible bacteria; for example, in 1922, he devised a special tellurite medium for cultivation of diphtheria bacilli, which is still of value to others. Again, he worked out special media (including synthetic media) for cultivation of tubercle bacilli, and he helped others to do valuable biochemical work with this organism. His wide knowledge, great 
experience and sympathy for the younger workers made him a particularly valuable member of many research committees.

Douglas's contributions to medical research must not be estimated merely by the publications under his name, significant though these are, but also by the great influence he exerted on the work of others; and only those who had the privilege of working with him or under his guidance can know how great this influence was, just as only those few could realise his great unselfishness and innate kindliness.

Douglas was elected a fellow of the Royal Society in 1922 and of the Royal College of Physicians in 1933. He was an ardent field naturalist, particularly interested in birds; he wrote two papers on the migration of woodcock, and presented bird skins which he had collected to the British Museum (Natural History).

P. P. L.

\section{Prof. A. S. Hitchcock}

Bx the death of Prof. A. S. Hitcheock on December 16 at the age of seventy years, the United States has lost one of its most distinguished botanists and the world its foremost agrostologist. $\mathrm{He}$ died on board the liner City of Norfolk, in which he was returning to the United States after visiting various European herbaria and attending the International Botanical Congress at Amsterdam.

Albert Spear Hitchcock was born at Owosso, Michigan, on September 4, 1865. He received his education at the Iowa State Agricultural College where he took his B.S.A. degree in 1884, and his M.S. and Sc.D. degrees in 1886 and 1920 respectively. From 1885 until 1887, he was first assistant chemist and later instructor at the above college. Then followed a short period as botanical assistant at the Missouri Botanic Garden, while in 1892-1901 he was professor of botany at the Kansas State Agricultural College. In 1901, he joined the staff of the United States Department of Agriculture as assistant agrostologist, becoming systematic agrostologist in 1905 and at the same time custodian of the Section of Grasses in the United States National Herbarium. Since 1924, he has been the principal botanist of the Bureau of Plant Industry, in charge of systematic agrostology.

Hitchcock's botanical work may be conveniently divided into two phases. The first was mainly occupied with teaching, but during that period he published a number of papers on the plants of Kansas, Iowa and Florida, and as a result of his trip to the West Indies (1890-91), an account of the plants collected in the Bahamas, Jamaica and Grand Cayman. The second phase, commencing with his appointment as agrostologist at Washington, was one of specialisation. At the National Herbarium there, he built up with the assistance of his colleague, Mrs. Chase, a large grass herbarium estimated to contain more than 210,000 sheets of specimens, and a very fine private agrostological library. His publications on the Gramineæ are exceedingly numerous and form a most valuable series of contributions to our knowledge of that very important family. They range from short papers containing descriptions of new species to complete grass floras of such regions as Peru, Bolivia and Ecuador, Central America, West Indies (with A. Chase), Hawaiian Islands, etc. For his own country, he produced in 1920 an account of the "Genera of the Grasses of the United States", and in 1935, a "Manual of the Grasses of the United States"-the latter a monumental work containing descriptions and illustrations of about 1,100 species. $\mathrm{He}$ also continued the account of the Gramineæ in the North American flora. Two other works which deserve special mention are his "Text-Book of Grasses" (1914) and "Methods of Deseriptive Systematic Botany" (1925). It is understood that a new edition of his "Genera of Grasses of the United States" is in the press, and that a revised account of the "Grasses of the West Indies" has been prepared.

Prof. Hitchcock travelled extensively to study and collect grasses in many parts of the world. In addition to visiting all the American States, he made expedi. tions from 1906 onwards to Cuba, Mexico, Panama, Costa Rica, Nicaragua, El Salvador, Honduras, Guatemala, West Indies, Hawaii, British Guiana, Japan, China, Indo-China, the Philippines, Peru, Bolivia and Ecuador. In the summer of 1929 he was invited to attend the combined meetings of the British and South African Associations for the Advancement of Science in South Africa, when he gave a paper on the "Relation of Grasses to Man". This trip enabled him to make numerous gatherings of grasses in South Africa, and on the return journey, in Southern Rhodesia, Tanganyika Territory, Kenya Colony and Uganda. At one time or another he had visited all the more important herbaria of Europe for the purpose of examining the type-specimens of American species described by European authors.

Prof. Hitcheock took a great interest in the thorny subject of botanical nomenclature, and acted as chairman of the Committee on Generic Types and the Standing Committee on Botanical Nomenclature appointed by the Botanical Society of America. In this capacity he took a leading part in preparing the "Regulations for Fixing Generic Types" (Science, n.s. 49, 333-336 (1919)) and the "Type-basis Code of Botanical Nomenclature" (Science, n.s. 53, 312-314 (1921) ) issued on behalf of the Society. During the period 1923-30 he worked in conjunction with certain British botanists in an attempt to reconcile the con. flicting views then held on nomenclature-an attempt crowned with success at the Fifth International Botanical Congress held at Cambridge in 1930. He also took part in the nomenclatural discussions at the Sixth Intermational Botanical Congress, Amster. dam, 1935. His "Methods of Descriptive Systematic Botany" forms a useful introduction to nomenclature as well as to taxonomic methods.

We deeply regret the passing of so kind and able a colleague-one who had accomplished so much, and who for the future had made ambitious plans whereby his vast knowledge of the Gramineæ was to be utilised in preparing, with the collaboration of Mrs. Chase, a classification and a descriptive account of the genera of the world's grasses. 